\author{
Radojka Vukčević* \\ University of Belgrade \\ Faculty of Philology \\ Belgrade, Serbia
}

\title{
REVOLUTIONARY VIBES OF 1968 AND THE AMERICAN DREAM
}

\begin{abstract}
One of the key questions to be discussed in the context of the 1968 protests is that of the American Dream. It has been woven into the fabric of everyday life, playing a vital role in who Americans are, what they do, and why they do it. It has always had the strongest influence on American individual and collective life. The focus of this paper will be to what extent it really exists and to what extent it is a product of the American imagination. How far has its imaginative territory reached? How much has the changing face of the Dream informed politics, everyday life and even the nation's identity itself? How have Americans created themselves through an idea that no one can completely define but everyone wants a piece of?

The notion of the American Dream can be traced back to the Depression and WWI when it ironically also faced its biggest threats. Here, the focus will be on the counterculture years of the late 1960s and 1970s, when it was put to the greatest test since this idiom was coined. Finally, the Dream will be followed from the year 2000 up to today, showing that it is as powerful and relevant as ever. It seems that the Dream will not only continue to be a compelling part of the American landscape, but is also taking a global form. It will most probably serve as a central guiding force for both Americans and others across the globe in the years to come.
\end{abstract}

Keywords: American Dream, counterculture, 1968 protests, genres, Cyberspace, global view

E-mail address: vukcevicradojka@gmail.com 


\section{Harlem}

What happens to a dream deferred?

Does it dry up

Like a raisin in the sun?

Or fester like a sore-

Etc. And then run?

Does it stink like rotten meat?

Or crust and sugar over-

Like a syrupy sweet?

Maybe it just sags

Like a heavy load.

Or does it explode?

By Langston Hughes

\section{Introduction}

What is the American Dream? Does it still exist? Is it perhaps only a product of American imagination? If it is only imaginative, how far has its imaginative territory reached? If realistic at the same time, what role does it play in defining American identity, and the choices Americans make? Has it still a strong influence on American individual and collective life? What can its history tell us? More specifically, what role did it play 50 years ago? How far and in what ways have revolutionary vibes been reflected through the American Dream since then? How much has the changing face of the Dream informed politics, everyday life and the nation's identity itself? How have Americans created themselves through an idea that no one can completely define but everyone wants a piece of? What is it like NOW? Is it only American? European? Global? Human? Ethical?

Our common response to the questions raised would be that the 1968 revolutionary vibes are reflected in different environments, across both geo-political and genre borders, from literature, through film, to art. They challenge the policies of gender, race and ethnicity and at the same time leave a legacy that inspires a new way of thinking and writing about society and culture. The American Dream sheds light on virtually every major definition of American culture, past, present, and future. Revolutionary vibes have always been there reflecting themselves strongly through the American Dream both locally (USA) and globally. Somehow the very essence 
of the Dream itself kept reminding many in the US of the need for protest and change whenever it was threatened with destruction or corruption. The strongest and most alarming crisis happened in 1968 when Martin Luther King Jr. was assassinated, and this was followed by the eruption of anti-war and student protests in the US, the UK, and across the world. The responses in the light of the American Dream kept coming from many genres in literature, film, theatre, performing arts, visual arts and music. They have never stopped creating their own history to become increasingly relevant and very strong today targeting, among other things, some of today's most challenging issues, such as the environment, economics, and the changing relationships between the US, UK, and Europe. What they never ceased to do is to raise the old question:

\section{What is the American Dream?}

The American Dream takes the position of an umbrella covering some of the 1968 revolutionary vibes, such as the environment, place and protest of the titled topic. It challenges the policies of gender, race and ethnicity and inspires a new way of thinking and understanding society and culture. It corresponds to Lawrence R. Samuel's statement that the American Dream sheds light "on virtually every major definition of American culture, past, present, and future." (Lawrence 2012: 1-2)

Revolutionary vibes have always been there reflecting themselves strongly through the American Dream both locally (USA) and globally. Somehow, the very essence of the Dream itself kept reminding many in the US of the need for protest and change whenever it was threatened with destruction or corruption. The strongest and most alarming such threat happened in 1968 when Martin Luther King Jr. was assassinated, followed by the eruption of anti-war and student protests in the US, the UK, and across the world. The sixties kept reiterating "the necessities of change" (WagnerMartin 2013: 47-79), and the dream through its various emanations has never stopped creating its own history since, to become again very strong NOW targeting, among other things, some of the questions, such as the environment, economics, and the changing relationships between the US, UK, and Europe.

However, a short survey of the definition of the American Dream shows its complexity being reflected in the definition itself. Lawrence R. 
Samuel points out that the Dream is not real but "the guiding mythology of the most powerful civilization in history." (Lawrence 2012: 1) It is, as he believes, the best way to understand America, and, most probably, its social, historical, political, and cultural roots and routes of the current moment, and its potential futures. Real or not, a quick Google search done in 2012 returns 67 million hits. Current debates on health insurance and Social Security, the role of government, and the personal loss that comes "with a foreclosure are certainly stepped in the dynamics of the Dream, a proof of its resiliency and enduring relevance." (2) The twenty-first century only followed the previous one with the American Dream serving as the backbone of great social movements (New Deal, the Great Society). It was also the backbone in the cases of the counterculture and feminist and civil rights movements with its grounding in the ideal of equal opportunity, and it will play an important role in any major economic, political, or social encounter. It promises, especially with the rise of multiculturalism and global migrations, to become "a key denominator and unifying force." (3)

\section{History}

The American Dream is as old as the world, and it can be traced back to the birth of civilization. However, as it is well known, it was defined in $17^{\text {th }}$ century America and formally articulated in the Declaration of Independence and Constitution. The concept of the American Dream included many things: meritocracy versus aristocracy, the position in life which is earned not inherited, key words and concepts such as opportunistic, self-reliant, pragmatic, resourceful, aspirational, optimistic, entrepreneurial, inventive. The Dream encompasses many desires ranging from some of the oldest such as owning a piece of land to that famous desire of the Great Gatsby: to reinvent oneself. The list of successful and unsuccessful dreamers is long. James Truslow Adams is credited with first using the phrase while Dale Carnegies, Newman Vincent Pale and Horacio Alger have served as some of the loudest spokesmen. Some historical figures such as Jefferson, Franklin and Lincoln, and among a myriad of illustrious characters who made the American Dream come true and became the embodiment of the Dream: Babe Ruth, Elvis Presley, Frank Sinatra, Irving Berlin, Sam Walton, Ray Kroc, Mickey Mantle, the Jackson Five, Henry Ford, Walt Disney, Arnold Schwarzenegger, Hugh Hefner, Oprah Winfrey, Donald Trump and Barack 
Obama. Some iconic works (from Death of a Salesman to The Sopranos, as well as the works of Frank Capra and Norman Rockwell) are considered to be definite manifestos of mythology and it can be accepted that the American Dream is "as American as Mom, apple pie, and Chevrolet, the purest, boldest expression of who we are as people". (4)

However, despite its constant presence, the American Dream has never been a straight line. It has experienced its ups and downs, and has adapted its meaning to the cultural environment (independence, a new Cadillac, a good health insurance plan). It has been equally adopted by the Right and the Left (the Republican and Democratic principles); radicals and conservatives, spiritual and secular, it is mutable and amorphous, and thus "the Zelig of mythologies, able to transform itself to fit virtually any situation or cause". (4-5) Its history has shown how astounding its breadth and scope are! Many of the American desires and expectations are embedded in the Dream (hope for a better tomorrow, the entrepreneurial spirit, the sacredness of home, the seductiveness of wealth, the pressure to succeed, American fascination with "hope" and "change", and belief that "anything is possible"). It is also seen as American civil religion, or as a success story and a dream of consumption. Still, it is more coherent than it looks at first sight, and Samuel Lawrence concludes that its scope only contains various incarnations (equal opportunities, limitless possibilities, a better and happier future, a home of one's own, going from "rags to riches", to be one's own boss, to achieve more than one's parents), which are but variations of one and the same theme and its progressive, utopian character. At the core of the American Dream there is a hope that tomorrow will be better than today.

The history of the American Dream discovers its many complexities starting from upward mobility, which has embodied the essence of the American Dream for many in both the working class and the middle class. However, recent studies show that upward mobility is even a greater myth than the Dream itself. They point out the loss of faith in themselves and in their country that millions have recently experienced which is "the saddest part of the American Dream, every bit as tragic as the heroic stories of success." (7) The stories of success also remind Americans that they live in a "land of opportunity offering all citizens an even playing field, on a grander level", the fact that they are a "chosen people assigned a unique and special purpose." (7) 
The American Dream has been employed in a variety of ways by a variety of individuals and institutions: it has often been used to challenge American idealistic principles, especially those concerning the issues of immigration, race, gender and religion; the Government has also employed it as a tool of propaganda, a powerful ideological weapon of persuasion both at home and abroad; it served as a convenient counterpoint to Communism (the famous "Kitchen Debate" between Vice President Nixon and Soviet Premier Khrushchev in 1959); finally, some use "the relative health of the Dream as a key social barometer, a way to determine if the country is moving forward or backward." (8)

It is not only individuals and institutions which employ it: it is embedded in almost every layer of American popular and consumer culture. American movies have responded to their times by presenting American myths with its important mythmakers: Walt Disney and Frank Capra. TV and radio have also presented the Dream, "with every sitcom family from The Goldbergs to The Jeffersons to The Simpsons trying to climb the ladder of success while facing the trials and tribulations of modern life". (8) Advertising, being appropriated by corporate America as a principal marketing strategy, plays the same role. Political speechwriters have used the American Dream very often and effectively, as well as many board games such as Monopoly, and sports themselves, which are often portrayed as metaphors of and for the Dream. Samuel Lawrence rightly concludes that the landscape of American popular culture from Jay Gatsby to Jay-Z "has been strewn with fragments of the Dream, the desire to beat the odds by making full use of our Godgiven talents perhaps our most compelling story." (9)

It has been present in American culture and in almost all of its genres offering its bright side but also carrying its dark side, its evil doppelganger just as powerful as its positive side. The negative side is easier to interpret as it opens up a plethora of questions. It points to the close connection between the rise of the self in the last eighty years and the American Dream as "the shift from civic and communitarian interests to personal and private ones has swung the mythology toward individual concerns." (9) It was during the Reagan years that the Dream shifted from "we" to "me". Over the next couple of years American dissatisfaction continued to grow and by the 2000s, the American Dream was now almost by definition unattainable. Its foundation in the Protestant work ethic and self-improvement eroded and was replaced by an ethic of self-preservation, social survival, and individualism. The new markers that conveyed the realization of one's 
Dream were: acclaim, admiration, envy and public recognition, concludes Samuel Lawrence. He is supported by one of its strongest critics, Noam Chomsky, who defined "the 10 principles of concentration of wealth and power" which were first presented on film and then in the book Requiem for the American Dream (Chomsky 2017: 1-151).

The cultural history of the American Dream can be followed through six major eras of mythology since the phrase was coined in 1931. It can be started with the Depression, to be continued with the postwar years, to be tracked through the counterculture years of the late 1960s and 1970s, "when the nation's idealistic faith in itself was put to the greatest test since the phrase was coined." (Lawrence 2012: 11) The 1980s are discussed along the dividing line of "haves" and "have-nots" while the Dream of the 1990s is seen as the decade when the mythology was expected to turn real for many, although it largely did not. Finally, the sixth era discusses the period from the year 2000 up to now, and shows that the Dream's power and relevance have remained as strong as ever into the 21st century.

\section{0-1970}

The history of the American Dream is long and exciting. Nevertheless, the focus will be on the counterculture years of the late 1960 and 1970s which witnessed an intense investigation of the state of the American Dream. Revolutionary times worked together on developing the American Dream but now people were more independent and it became more of a solitary affair. The standard of living was lower, and "combined with the social and political chaos of the past few years, was a clear sign that the American Dream was in decline." (73) The key question often raised at that time waited for an answer if it would recover, when and how? That is why the sixties put protest in its focus both as a weapon and a metaphor (Вукчевић 2018: 481-485).

One of the answers came from President Lyndon B. Johnson in 1965, who proposed to create a "Great Society" while emphasizing the democratic foundation of the Dream. J. R. Wiggins, editor of the Washington Post, just two weeks after Lyndon B. Johnson's 1965 State of the Union message wrote: 
The most persistent American dream, originating with the Founding Fathers and periodically recurring for 200 years, has been that of creating on this continent a Great Society resting upon a people made politically free, economically secure, universally literate, culturally sophisticated, politically wise, morally right and naturally good. (Lawrence 2012: 73)

It seems that after a series of wars, depressions, and other crises, America was ready to return to the original Dream.

Many believed that his vision could come true but not everybody. Some unoptimistic responses came from writers such as Norman Mailer and his great novel American Dream, a social critic of the crashing and burning of the American Dream. Not only did writers respond to the new possibilities of the American Dream but debates and other forms of hidden or open protest were also constantly going on. The clash between William F. Buckley Jr. and James Baldwin in 1965 is worth mentioning in which they were supposed to prove whether "The American Dream is at the expense of the American Negro" with Baldwin taking the "for" position (544 students voted for him) and Buckley the "against" (164). This ideological division reflects the split between the Left and the Right (against the idea of "Great Society") regarding the American Dream in the mid-1960s. Samuel Lawrence further widens this division by claiming that the representatives on the Left understood liberalism in the spirit of the American Dream by quoting Staughton Lynd who claims that the "New Left" (the liberal and sometimes political movement focused on social activism) was "a legitimate descendant of the American Revolution and the United States Constitution, something conservatives would dispute." (75) At the Yale Socialist Symposium in 1966 where he defined the Vietnam War as more "un-American" than his politics he said: "It is precisely the distinctly American Dream that all movements should be subordinated to human rights." (76) He was followed by many non-radicals in the mid-1960s.

Like many times before, such as during the Vietnam War, the protests for civil rights re-examined the very definition of the American Dream: what it was about and who could share it. In 1966 there were a few instances of racially motivated violence where white mobs attacked civil rights demonstrators protesting against segregated housing (Chicago). The conflict was based on the right to the American Dream: one group trying to preserve it and the other to win it. The blacks continued to fight for it for another couple of years - "using violence in cities across America to 
protest their exclusion from the American Dream." (77) Robert T. Pickett, "a twenty-year-old prelaw student at Kent State took advantage of the opportunity to share the information with Vice president Hubert Humphrey when he visited the university in 1968." (76) Humphrey, a candidate for the Democratic presidential nomination along with Senator Robert F. Kennedy (NY) and Eugene McCarthy (MN) referenced the American Dream in his speech before eight thousand students, during which many black "militants" and one hundred Vietnam War protesters walked out. As Samuel Lawrence quotes: "You say you believe in the American Dream. I do not believe in the American Dream simply because the American Dream does not believe in me. If it did believe in me we wouldn't have had any riots in Newark or Watts... the American Dream to me is the American nightmare...What will you do to restore my faith and my people's faith in America and the American Dream if you are elected?" (77) Some conservative political leaders interpreted racial unrest and violent war protests as signs that the country was out of control. Samuel quotes the words of George Romney in early 1968, the governor of Michigan and Republican presidential candidate who said that America was facing "a crisis in the American Dream at home and the American mission in the world."(77)

Two leading voices, two men who deeply believed in the American Dream were soon assassinated: Martin Luther King Jr, who preached in Memphis the night before expressing his faith in the Promised Land, and Robert Kennedy, committed to the American Dream principles (individualism, self-reliance, self-discipline and unending selfimprovement). Their deaths made many fear the threatening death of the American Dream. However, this did not happen. Samuel Lawrence quotes the comic description of the changes in the American Dream, by saying that instead of dreaming rich, they "began to dream hip", and suggested that the mainstream was adopting the counterculture's mantras to find him/herself and "do their things" instead of defining themselves by the things they owned. The quintessential American Dreamer was now the bearded hippie, "the realization that one was a member of the bourgeoisie a major bummer." (79) They wanted to liberate their "wild, free avantgarde persona from sodden prosperity ... the nouveau-riche generation having given birth to the nouveau-avant generation." (79)

Nevertheless, Samuel Lawrence argues that this was not an easy task for many individuals, for the pursuit of the persona is but a version of the American Dream, and many simply did not know how to become flower 
children, and quotes Morton who concludes that "for at least a segment of the adult population and a good many young people, the upwardly mobile, materialistic American Dream was decidedly out, replaced by a modern hedonistic and spiritual version." (79) In spite of many dystopian, negative and tragic voices, many optimistic still prevailed either as a call for a utopian paradise or a place of a happy, united and serene America.

Many responses to the idea of the American Dream came from the film industry. Samuel Lawrence singles out the role of John Wayne (True Grit, The Cowboys, The Green Berets) describing him as a "soothing tonic for the decade long nightmare that was Vietnam." (89) This was not the case with some of the greatest films of the late 1960s and 1970s which the American Dream turned upside down; "by featuring criminals as antiheroes, the Anti-Paradise of the counterculture years was an ideal climate for cinematic outlaws to pursue wealth and power" (Bonnie and Clyde, 1967; The Producers, 1968, Butch Cassidy and the Sundance Kid, 1969; The Sting, 1973; Paper Moon, 1973; and The Godfather trilogy). (89) Some other films (The Graduate, 1967; Easy Rider, 1969) glorified brave characters who broke the norms of the establishment while the Dream spinning out of control, a corrupt system encouraging individuals and institutions to do whatever necessary to succeed, was depicted in films like Nashville (1975) and Network (1976). Finally, he singles out Rocky, the film which redeemed them all, as its hero fights against all odds to reach the top, "endorsing the traditional values of the Dream along the way." (90) It is a celebration of the American Dream, and like many other films from this period it served as a stabilizing force for a "severely shaken" American Dream. It came as a remedy after "the angst of the early seventiesVietnam, Watergate, the Arab oil embargo, economic 'stagflation', a fading but lingering countercultural movement, rise in crime and civil unrest, and demand for minorities to have their voices heard-Americans were more than ready for narratives that reaffirmed their faith in the nation's ideals." (91) Thus, Rocky, released five months after the nation's bicentennial (1976) reminded the people (immigrants most of all) that the American Dream could still come true: it celebrated it.

It was very much alive for the white ethnic groups (Jews, Irish Catholics, Italians, Poles and Germans) who had higher incomes than the Episcopalians. The American Dream was also true for the "eastern and southern European Catholics-for whom by definition it was not supposed to work well." (100) The door of multiculturalism was more widely open 
as $37 \%$ of Americans now approved of interreligious marriage, compared to $20 \%$ of a decade earlier. Still, many efforts were made to have the American Dream updated and refined like that expressed through the exhibition America Dreams On organized by the California Museum of Science and Industry in Los Angeles in 1976-77. The visitors were exposed to the voices of the people "who captured its essential spirit (including not only John Wayne but also the Beach Boys, Paul Simon, and the Beatles)" (101), and they were invited to write down their own American Dream. They only confirmed the old truth: the more things changed, the more they remained the same.

Samuel Lawrence concludes that traditional understanding of the American Dream was on the rise at the end of the 1970s. Television began changing its tune by producing Taxi, based on a story about the American Dream. CBS news aired American Dream, American Nightmare-the Seventies (1979), which looked back at the Vietnam War, Watergate, and the bicentennial celebration. The show suggested that the government played an important role in their loss of idealism, and that the American Dream was not compatible with the optimistic view of the future. Economic woes, an energy crisis, government scandal, racial tension, two assassinations, and an unpopular war "did major damage to the ideals of both the great Society and the counterculture, and, correspondingly, the ideals of the Dream." (103) American society was moving backwards.

It was moving backwards, but not for a long time. The early eighties brought what reporter Ted Green called "national catharsis" thanks to the victory of the US Olympic hockey team over the Soviet team at Lake Placid. The Dream was revived by reminding Americans that "traditional values of hard work, dedication, and team spirit had not been completely thrown into the dustbin of history and that dreams could really come true." (105) The demand for more myth-makers had become stronger and it was clearly expressed by Herbert I. London and Albert L. Weeks in Myths That Rule America. They believed that the answer to the development of the American Dream was in re-memory of the American past and its myths of Eden, industry, achievement, individual freedom, and optimism. They believed in its revival but not everybody was optimistic: pros and cons kept changing places. (107)

Negative answers came from popular culture as well. Rock music continued to sing of love and sex, unemployment, poverty and loss of hope in the American Dream. The blues was sung for the American Dream 
among the working class hitting the economic wall by Bruce Springsteen (Darkness on the Edge of Town; The River, Nebraska) with the saddest and most serious album about the American Dream Born in the U.S.A, about economic hope, security, and community. TV also responded to the tough times of the early 1980s. In the era of Dallas, The Waltons, and Soap, a new realistic show called The American Dream (ABC, 1981) addressed money issues, unplanned babies, and sick relatives. Film reacted to the American Dream by reinforcing the domestic orientation in Steven Spielberg's 1982 E.T.: The Extra-Terrestrial, as well as in The Wizard of $\mathrm{Oz}$ and Scarface. The search for the American Dream in this decade is best expressed in two films about baseball: The Natural (based on Bernard Malamud's 1952 novel) and the 1989 Field of Dreams (based on W. P. Kinsella's 1982 novel Shoeless Joe).

A good way for women and people of color was franchising while other minorities (Koreans and other Asian-Americans) were defining their American Dream in more traditional ways. They were not concerned with the future the way many American intellectuals were, such as Philip Moffitt who asked if the dreams of Generation X would be any different from babyboomers' dreams, and suggested re-articulation and redefinition of the American Dream which would answer the postmodern promises, embrace American traditional values but also adjust to the "new self-image-a view of tomorrow that reflects the lessons of the last fifty years." (122) This is only one of the voices in pro and con discussions constantly reexamining the place and definition of the American Dream in the 1980s. Perhaps the strongest voice came from the TV show thirtysomething, a major hit for $A B C$ in the late 1980s and early 1990s, especially popular among "young urban professionals who related to the characters' 'yuppie angst". (133), the generation which was fighting with uncertainty and alienation while pursuing the American dream. It was not easy to find out how real it was but for Thomas Cangelosi of the New York Times it was easy to conclude that intellectualism was boring, idealism impractical, and emotionalism self-destructive, so that "his generation has decided to swallow a pill delivering a heavy dose of conservatism and simplicity." (134)

The 1980s made the American Dream cross the borders of the US and enter the space of Europe and the question is asked if the American Dream should be renamed the European Dream. Many Europeans enjoyed a lifestyle resembling the standard of the American Dream, while many Americans did not. The American Dream became more and more privatized, 
illustrating the concentration of wealth and widening gap between the rich and the poor. The myth was still present but "the reality greatly different, especially among the middle class for whom the Dream meant so much." (135) One of the omnipresent moments: rethinking and re-creating the American Dream was waiting for its time at the very end of the $20^{\text {th }}$ and the beginning of the $21^{\text {st }}$ century.

The very end of the $20^{\text {th }}$ century learnt from the very successful production of Arthur Miller's Death of a Salesman (1999), with its 274 performances and a number of Tony Awards, that the American Dream was still the American guiding mythology in everyday life. Still, at the beginning of the $21^{\text {st }}$ century it was an elusive, slippery thing, coming and going like a thief in the night. (137)

The beginning of the last decade brought creativity, compassion and connection as hallmarks of the 1990s. The early 1990s did not bring prosperity and abundance as people expected. The implosion of the American Dream was best illustrated in film, especially by Michael Moore's 1990 Roger and $\mathrm{Me}$, which was described more as a social commentary than a documentary. (138) Moore said that the film is about the American Dream:

The dream itself isn't good because it's a dream, it's not reality. Being able to own your home and own your car is not the reality of being in control of your own life, because they can snap it from you just like that. I don't want you to be angry about the dream being gone. I want you to be angry about the lie of the dream, the illusion that's created, the illusion that by having a few things of wealth that somehow you've made it and you're secure for the rest of your life. (Moore in Lawrence 139)

It was becoming clear that the American Dream was an illusion that the Americans had created for themselves, and the discovery that upward mobility was "difficult if not impossible for a big chunk of Americans was a devastating blow to belief in the American Dream". (139-140) An old demand for its restoration reentered the scene. Many voices for its affirmation were heard. The voice of protest came as a result of the fact that the American Dream started to mean an ideal of prosperity - not liberty!

In the meantime, while fighting for its traditional meaning the American Dream made an emotional bond with sports, baseball most of all! 
However, even greater was the one it shared with movies. The documentary Hollywoodism that aired on A\&E in 1998 "wonderfully captured the intimated relationship between movies and the American Dream, showing how much DNA they had in common." (153) Hollywood's Jews expressed the Dream's longing for happiness, success, and acceptance (producers: William Fox, Adolph Zukor of Paramount, Louis B. Mayer, Jack Warner, etc.). The spread of capitalism and the global economy had much to do with the transnationalism of the Dream which, for those staying in the US, meant more hard work to achieve it. It was illustrated by Linda Schaffer's 1996 documentary American Dream with celebrities (Michael Jordan, Mel Brooks, Gloria Steinem and Maya Angelou) who showed that they still had not made it. Neither have many of the interviewed minorities, first of all Native Americans or Asian Americans.

The American Dream kept rising and falling, proving to be too perfect to happen although America was more prosperous in 1995 than 1945. Quoting Robert J. Samuelson, Lawrence writes: "That the 'Good Society' of the 1950s and 'Great Society' of the 1960s (as well as the counterculture, it could be said) never fulfilled their full promises-continually rising incomes, stable jobs, and the end of poverty, racism, and crime-was disappointing if not traumatic to the nation ... exposing the American Dream as a fantasy". (157) The gap between the "haves" and the "havenots" kept growing as well. Self-reliance once again became a key marker of the American Dream while individual initiative, personal responsibility and talent became the new necessities. The American Dream came to a full circle from its origins to the personal freedom.

Politicians found it a useful device to get elected, Democrats and Republicans equally. Thus, both Bill Clinton and Bob Dole, 1996 candidates for President "were clearly trading on Martin Luther King's concept of the Dream, specifically his 'The American Dream' speech made in 1961 at Lincoln University in Pennsylvania and his 'I Have a Dream' speech made in 1963 on the steps of the Lincoln Memorial". (159) Clinton and Dole relied on King's use of the American Dream having in mind that its power relies on the nation's well-known founding principles ("that all men are created equal, that they are endowed by their Creator with certain unalienable Rights, that among these are Life, Liberty and the Pursuit of Happiness").

The end of the century (1997) brought "the good old days" with prosperity, the end of recession, while many families "were catching up to where they had been in terms of their standard of living, the American 
Dream once again in their sights." (162) However, the end of the century opened another arena for its realization - cyberspace. It opened many things the dreamers had wished for: freedom, success, prosperity, it became the place of limitless opportunities. Cyberspace opened itself to the many all around the globe and as Kenji Sato said in 1997, it "has become the ultimate embodiment of the American Dream." (163) This new promised land, relevant for people around the world, incorporated the same values of the United States at its best. (Trump as the embodiment of the 1990s). The Americans themselves were not just creating but they were living it. (165) As soon as they crossed over into a new century, they started living the American Dream in a way they did not expect or foresee.

Even with the economy crashing in the early 2000s (much like in the early 1970s, 1980s, and 1990s), Americans were determined to keep their Dream alive. Both the advantages and the disadvantages of being born in the United States were greater than in many other countries with "the polarity of class here making social mobility more possible in parts of Europe". (171) Still, both classes needed it even as an illusion, which was a very useful and valuable one. That is why "the mythology of the American Dream persisted, with a Bill Clinton or Bill Gates taken as incontrovertible proof that the country was a level playing field on which anyone could potentially rise to the top." (171)

It was true that the American standard of living was the highest in history, but it was not without social problems, including high ratesof divorce, teen suicide, violent crime, prisoners, and depression. (172) Making more money was not a strong substitute for happiness, some of the authors point out (Myers, Schwartz), while others like Rifkin compare the European choice of happiness over money with the American, illustrating it by saying that Americans "live to work" while "Europeans work to live". The question Rifkin raises asks who was better suited to meet the challenges of the $21^{\text {st }}$ century. (173) Still, he understands the "European Dream" as superior to the American Dream (paid vacation, maternity leave, free or cheap health care, housing assistance, and tuition reimbursement from the government). He insisted that the American model of success and values (religious, patriotic, independent), that the tradition of isolationism, individualism, and self-sufficiency were not in "sync with where the world headed, he went further, with Europe's more communitarian approach better designed for the world of tomorrow." (174)

The American Dream, as it has previously been pointed out, was slowly changing its color: it was becoming more and more the dream of 
Latino Americans, Asian Americans and others. Soon it was very present in popular culture. The rise of television news helped to popularize the American Dream (Peter Jennings's 1998 book The Century; Tom Brokaw's 1999 book The Greatest Generation Speaks). In 2001 Dan Rather produced The American Dream Stories from the Heart of Our Nation, which was even more of an ode to American mythology. The American Dream was expressed in TV shows like Who Wants to Be a Millionaire? and Survivor but it was the 2002 American Idol "that most compellingly expressed the essence of the American Dream in the first decade of the twenty-first century ...tapping into a cultural nerve that reflected many aspects of the Dream, including our unabashed worship of celebrities and that we all perhaps had the potential of becoming one." (181) In 2006 it became ripe for parody with the film American Dreams, the show which turned the American Dream upside down. It was not the same with the TV show The Sopranos, that revealed the depth and range of the American Dream. It had a wide reception ( 5 books of criticism from different points of view), and in one of them it is said that "no other TV show had gone to the dark side of the Dream like The Sopranos... the series palpably illustrating what could and did go down when ambition lost its moral footing." (181)

Popular music (especially hip hop, with its adoration of money and the luxuries it could buy) was also a central repository of the American Dream in the media of the 2000s. Among many, Bruce Springsteen was now recognized as an authentic national treasure. Over the course of three decades, he created answers to the American Dream through his responses to 9/11, the 2002 album The Rising, "solidified his role as 'America's conscience, questioner and consoler." (182) Many books were written about him and he and his music were almost synonymous with the American Dream. Jimmy Guterman's Runaway American Dream, Robert Coles's Bruce Springsteen's America, and Jim Cullen's Born in the U.S.A. "each expressed this point in different ways, canonizing Springsteen as the Boss not just of pop music but, for a whole generation, of the American Dream as well." (183)

Bruce Springsteen sang about the working class, many white collar workers also saw the American Dream vanishing "as corporate America slashed staff to cut costs or for more urgent reasons." (183) The gap between the richest and the poor was widening and dragging the Dream down "with the big bulge in the middle falling further behind the top percent of income earners and doing everything they could to avoid becoming part 
of the bottom 20 percent." (187) This made Zuckerman compare the early twenty-first century with the Gilded Age. 15\% of Americans now possessed $85 \%$ of the nation's wealth, "with the bottom half accounting for just 2.5 percent of total household net worth." (187)

Hip Hop music is another example of how perceptions of the meaning of the American Dream have changed over the decades from its socially and racially aware protest songs in the 80s to a "Get Rich or Die Trying" vision of the American dream in the new millennium. Over the decades capitalism dulled hip hop's razor sharp social and racial criticism, pushing it into the mainstream's grip. At present time, hip hop music is the mainstream in the true sense of the word (especially in the USA) - all global pop stars collaborate with Hip Hop rappers and producers, it is the quick formula for success. It is an interesting phenomenon that hip hop is at the moment the most popular music genre, even though the messages that mainstream hip hop conveys are devoid of deeper meaning and focus solely on material and corporeal pleasures, comforts and gain, which is an indicator of the Zeitgeist of the American Dream.

In the aftermath of 9/11, the drawn-out war in Afghanistan, the economic downturn of 2008, myriads of political scandals, the international immigration crisis, racial tensions, and marginalized citizens have all set the stage for events that have people trying to capture the illusive American Dream. Protests are on the rise in the US. Some recent examples are:

- $\quad$ Colin Kaepernick and other US football players who knelt during the national anthem to protest police violence against African-Americans, they were making a gesture of humility, of pain and distress but these players have been strongly criticized for disrespecting the flag and fallen service members.

- $\quad$ Recent women's marches (in the US and abroad) have been in response to inequality that women (of all ethnicities) face in the workforce and in society.

- The March for Our Lives, in March 2018, drew record numbers of people protesting against gun violence (especially in schools) and for gun law reform. It is important to point out that these marches were completely organized through social media within a short amount of time. 
The protests are different in nature to the protests of the 1960s, namely these are non-violent, non-threatening. For example, kneeling during the national anthem is a gesture of humility, not ominous ire like the Black Power salutes raised by Tommie Smith and John Carlos at the 1968 Olympics. What do all of these have to say about the state of the American Dream today? Do they not also express what the previous generations kept asking for: the good old humane American Dream? Is not this same need being constantly expressed not only in the US but all over the globe - thus turning the American Dream into a global one?

\section{Conclusion}

It is almost impossible to give a definite answer to the question of the definition of the American Dream. Research has shown that it still depends a lot on what one believes. Some believe that they have lived it, which makes the mythology real. Still, living the American Dream can also have nothing to do with mythology itself but rather being in the right place at the right time. Another definite answer has been strongly confirmed: the American Dream has constantly played the role of an umbrella, embracing many genres, which keep giving their responses to their time. Its impact on Americans and the nation as a whole is enormous. It is a part of every aspect of American culture. It plays different roles: a utopian ideal functioning as a beacon of hope; a common denominator which helps bring Americans together (multiculturalism); a user-friendly vehicle for assimilation (to be an American and retain one's own ethnic identity at the same time); a masterpiece embraced by many.

The American Dream keeps coming and going, and seems to be living in the past and future more than in the present, with its best days behind it. Its crashing and burning in the late sixties was a predictable phenomenon for many. The wave of economic boom crashed and the American Dream with it! Due to a strong connection between happiness and the American Dream (family and economic security), most Americans still want to reach it and believe that doing so will make them happier people. However, rising inequality and falling real wages have exposed upward mobility, making many of them realize the US is not the "opportunity society" they have always believed it to be.

The question to be raised in the conclusion concerns the millennial generation and their chances of living the American Dream. The answer 
is positive as long as they compare it with the other parts of the world where it has a strong impact. It is also positive as long as they protest while asking who stole their American Dream (the 2011 documentary Who Stole the American Dream?) or organizing protests like the Occupy Wall Street movement and the civil protest at the Wisconsin Capitol in early 2011. It is now being studied retrospectively as well: the assassinations of Martin Luther King Jr. and Robert Kennedy; gay rights, women' rights and civil rights; the Black Panthers and the Vietnam War; the New Left and the New Right. The Year 1968 has been studied from the vantage points of its historical, political and social legacy. Special attention has been focused on how protest itself has transformed in the US, from Students for a Democratic Society and the Civil Rights Movement in the late 1960s, through the Women's Movement in the 1970s, towards the contemporary visibility of the Tea Party and the Occupy movement. (See: Reframing 1968: American Politics, Protest and Identity).

The very cultural history of the American Dream supports American optimistic beliefs reminding us that the American Dream would always recover in the past. The incessant waves of immigrants to the US will breed ground for the American Dream as they believe in the mythology most strongly, while politicians will continue to employ it in their campaigns. This optimism is supported by a 2010 survey in which it is said that 34 percent of Americans believed that in spite of the bad economy they had achieved it. Above all, it must be pointed out that creativity is the most important social and economic currency, and one's imagination to develop new and original ideas and things is the best recipe for success, which will never go out of fashion!

The American Dream will survive and perhaps even flourish in the US in the future because the American Dream is not solely American. It will be shared with other countries. The Americans have invented and mastered the fine art of the American Dream, but many countries globally enjoy their own interpretations of it. As the world plunges further into the $21^{\text {st }}$ century, the American Dream is on the way to becoming the Global Dream as it embodies the most essential issue such a dream should contain - to be crowned as an ethical Dream! 


\section{References}

Chomsky, N. (2017). Requiem for the American Dream, Created and edited by P. Hutchison, K. Nyks \& J. P. Scott, New York Oakland London: Seven Stories Press.

Halliwell, M. and N. Witham (eds.) (2018). Reframing 1968: American Politics, Protest and Identity. Edinburgh: Edinburgh University Press.

Hughes, L. "Harlem". Zangrando, J.S. and R.L. Zangrando. "Black Protest: A Rejection of the American Dream" (2018), <http://about. jstor.org/terms>, downloaded from 34.248.21.60, (16 June 2018) 12:42:38UTC.

Lawrence, S. R. (2012). The American Dream: A Cultural History. Syracuse New York: Syracuse University Press.

Вукчевић, Р. (2018). Историја америчке књижевности. Нови Сад: Академска књига; Матица српска - Друштво чланова у Црној Гори. Wagner-Martin, L. (2013). A History of American Literature. Oxford: WilleyBlackwell.

Received: 30 November 2018

Accepted for publication: 28 December 2018

Радојка Вукчевић

РЕВОЛУЦИОНАРНЕ ВИБРАЦИЈЕ 1968. ГОДИНЕ И АМЕРИЧКИ САН

\section{Сажетак}

Протести 1968. године отворили су много питања од којих је једно од најзначајнијих Амерички сан. Будући да је уткан у сваки сегмент свакодневног живота, он игра виталну улогу у дефинисању америчког идентитета, индивидуалног и колективног живота Американаца. Много тога се претпоставља о његовој улози, због чега је рад поставио себи за циљ да истражи меру његове присутности у реалном и имагинативном свету. Испитивање његовог присуства у реалном свету отворило је и питање улоге политике не само при његовом дефинисању, већ и при дефинисању појединачног и националног идентитета. Испитан је и процеп у потешкоћи давања његове заокружене дефиниције и константне жеље сваког појединца да узме макар комадић сна. 
Иако се трагови Америчког сна могу пратити далеко раније, рад је ставио акценат на контракултуру с краја шесте и седме деценије двадесетог века, када се сан нашао на највећој проби од тренутка када је скован. У раду се даље пратио историјски преглед развоја Америчог сна и посебан акценат стављен је на период од 2000. до данас да би показао да је Амерички сан и даље снажан и релевантан. Истраживање је исто тако показало да ће Амерички сан и даље трајати не само у Америци, већ глобално. Највероватније ће имати централну и водећу улогу и за Американце и за многе друге становнике овог света у годинама које су пред нама.

Кључне речи: Амерички сан, контракултура, протести 1968, жанр, Cyberspace, глобални поглед 